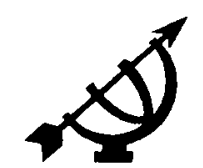

\title{
Waarde-uitklaring: Trojaanse perd in Suid- Afrikaanse skole?
}

\author{
Jeanette de Klerk \\ Departement Opvoedingsbeleidstudie \\ Fakulteit Opvoedkunde \\ Universiteit van Stellenbosch \\ STELLENBOSCH \\ E-pos: jdkı@maties.sun.ac.za
}

Abstract

Value clarification: A Trojan horse in South African schools?

This article entails an analysis of and a critical reflection on the value clarification approach to value-education. Questions that need to be answered are inter alia: Is value clarification perhaps an approach that offers an answer to the problem of moral pluralism in South Africa? What are the potential dangers of this approach? The origins of this approach are traced back to humanism, humanistic education and the human potential movement. It is suggested that the value clarification approach can lead to moral subjectivism, problem- and process-centredness and an overemphasis of personal emotions. Potential dangers of this approach for South Africa, where a lack of common values exists, are also highlighted. These dangers include individualism, relativism, narcissism, an egocentric "me first" attitude and the overall unacceptability of value neutrality in an educational situation, as well as of the absence of virtues and character and lack of recognition of social and historical concience.

From a Biblical-educational point of view the approach of value clarification is unacceptable because of its humanistic basis. This article contains a warning for parents and teachers not to accept the value clarification approach to moral education as an easy solution to the moral threat in South African schools, but rather to see it as a potentially dangerous approach that could in fact contribute to the moral decline and erosion of authentic values. 


\section{Agtergrond}

Suid-Afrikaners beleef tans ' $n$ intense morele krisis, nieteenstaande die feit dat die konstitusie in "waardetaal" geskryf is en die individu se vryheid en regte sterk beklemtoon word. Die dringende uitdaging om waardes te vestig word deur die land se hoë misdaadsyfer, die grootskaalse korrupsie en minagting van die reg beklemtoon. Daar is 'n toenemende besef dat die vestiging van die waardes wat 'n beskaafde samelewing onderlê, hoë prioriteit moet geniet, veral in die lig van die feit dat die sukses van 'n demokratiese samelewing in die laaste instansie op die kwaliteit van die karakter en morele krag van individue berus. Hierdie morele krisis is nie net waar van Suid-Afrika nie, maar dit is ' $n$ internasionale tendens, wat in mindere of meerdere mate in alle lande aangetref word.

Die nuwe uitkomsgebaseerde benadering tot onderwys sluit verskeie waardegebaseerde aspekte in, maar daar is geen duidelikheid oor die mate waarin daar vir waardeopvoeding voorsiening gemaak word nie en ook geen rigtingbepalers oor hoe waardes suksesvol gevestig kan word nie. In die soeke na 'n gepaste benadering vir die vestiging van waardes is een van die belangrikste debatte juis die debat rondom die evaluering en keuse van 'n benadering of benaderings wat geskik sal wees vir die situasle in Suid-Afrika in die tyd van transformasie en verandering. Die doel van die artikel is om een van die benaderings wat tans taamlik ondersteuning geniet in Suid-Afrika en ook internasionaal, naamlik die waarde-uitklaringsmodel, te ondersoek. Die benaderings tot die vestiging van waardes in skole berus hoofsaaklik op die individu se reg en vryheid om self te kies wat vir hom/haar waardevol is. In die lig van die pluraliteit van waardes in Suid-Afrika en die feit dat jong mense in ' $n$ gefragmenteerde samelewing gekonfronteer word met botsende en mededingende waardes, lyk dit asof die waarde-uitklaringsmodel 'n oplossing kan bied, juis omdat daar by dié benadering geen konsensus oor waardes is nie, morele voorskriftelikheid vermy word, en die individu nie ondergeskik gestel word aan enige groep nie.

In die artikel word 'n analise gemaak en krities evaluerend gekyk na die moontlike voor- en nadele van die waarde-uitklaringsbenadering asook na die toepaslikheid daarvan al dan nie vir Suid-Afrikaanse skoie. Is dié benadering dan nie dalk die oplossing tot die probleem van morele pluraliteit nie? Is 'n benadering waar gelykheid en individuele vryheid beklemtoon word, nie by uitstek geskik om demokratiese waardes in skole te vestig nie? In teenstelling met hierdie optimistiese perspektiewe behoort die kritiese waarnemer versigtige, dog dringende vrae te stel oor die implikasies van die benadering: Bestaan die moontlikheid dat die oorbeklemtoning van eiebelang en die gevolglike afwesigheid van morele 
aanspreeklikheid die gevare van morele verwarring en die uiteindelike ondermyning van 'n demokratiese lewenswyse en veral van 'n Bybelgefundeerde lewensbeskouing inhou? Indien dié gevare 'n werklikheid is, is ons nie dalk besig om die spreekwoordelike Trojaanse perd in ons skole te verwelkom nie?

\section{Analise van die waarde-uitklaringsmodel}

\subsection{Filosofiese uitgangspunt}

Value clarification as an approach to moral education is not built on religious traditions and the moral traditions associated with them, but on a secular basis, which has its origin in humanism, humanistic education, the human potential movement, and humanistic psychology (Van der Ven, 1998:237).

Filosofies is dié benadering in ooreenstemming met Rousseau se siening dat die mens van nature goed is en die kind daarom aan homself oorgelaat moet word, sodat sy "natuurlike goedheid" na vore kan kom. Die sekulêre humanisme van die waarde-uitklaringsmodel word deur sommige skrywers as negatief gesien, omdat dit hand aan hand gaan met personalisme en egosentrisme.

It emphasized rights more than responsibility, freedom more than commitment. It led people to focus on expressing and fulfilling themselves as free individuals rather than fulfilling their obligations as members of groups such as family, church, community, or country Personalism sprawned a new selfishness (Licona, 1991:9).

By die waarde-uitklaringsmodel val die klem hoofsaaklik op selfaktualisering en persoonlike emosies. Die benadering is meer gerig op die psigies gesonde, selfaktualiserende persoon as op die moreel opgevoede persoon. Dié populêre benadering het in 1966 sy beslag gevind met die publikasie Values and teaching deur Louis Raths, Merrill Harmin en Sydney Simon en die waarde-uitklaringsmodel het baie vinnig veld gewen en toegeneem in gewildheid omdat dit maklik aangeleer word, opleiding goedkoop en vinnig is, dit toepaslik is in verskillende areas en veral omdat dit maklik gebruik kan word by uiteenlopende groepe en in veranderende tye. Alhoewel Gairdner (1993:223) beweer dat dié benadering miskien nou verby sy hoogtepunt is, sien Van der Ven (1998:237) dit soos volg: "... humanistic education and especially the value clarification movement have continued to develop and are more popular today than ever before, even in religious schools and congregations".

Dié benadering gaan uit van die veronderstelling dat kinders meer sal omgee vir die waardes wat hulle self deurdink en uitgeklaar het as die 
Waarde-uitklaring: Trojaanse perd in Suid-Afrikaanse skole?

waardes wat deur volwassenes aan hulle oorgedra word. Voorstanders van dié benadering beskou dit as verkeerd indien sekere waardes voorgeskryf word, veral in 'n pluralistiese samelewing

They seem to assume that such things as honesty, property rights and human life are already valued by youngsters and, therefore the only difficulty is to choose among these values when they conflict. That is they assume a sort of natural goodness and integrity in the child whereby he or she will always want to do the right thing (Kilpatrick 1993:86)

\subsection{Die subjektiewe aard van waardes}

Die uitgangspunt van die benadering is die persoonlike en subjektiewe aard van waardes. Leerlinge word aangemoedig en geleer om hul eie waardes vrylik te kies. Dit is 'n nie-direktiewe metode en enige vorm van rigtinggewing deur ouers of onderwysers asook enige verbod of sosiale taboe word verwerp as indoktrinering. Daar word van die veronderstelling uitgegaan dat leerlinge hul eie morele besluite kan neem, sonder dat aandag geskenk word aan die vorming van karakter of die vaslê van deugde.

Dit is ' $n$ waardeneutrale benadering, geen waardes word oorgedra nie en geen voorbeeld hoef deur die onderwyser gestel te word nie. "The idea that adults should directly instruct children in right and wrong, or even try to influence students' value positions, was explicitly rejected" (Licona, 1991:11). Daar is geen gemeenskaplike waardes vir "ons" nie, maar slegs individueel vir "my" in 'n spesifieke situasie en tyd. Die sosiale konteks is nie 'n integrale faktor in die waardebepalingsproses nie en moraliteit word nie gesien in verhouding tot historiese, sosiale en filosofiese kontekste nie. Volgens voorstanders van dié benadering is alle waardes relatief, persoonlik en situasiegebonde.

\subsection{Proses-gesentreerd}

Die benadering is nie besorg oor die inhoud van leerlinge se waardes nie en wil nie 'n bepaalde stel waardes kommunikeer nie, maar wel die proses van waarde-uitklaring. Die klem val nie soseer op die inhoud van waardes nie, maar op die proses van waardekeuses, omdat waardes as vloeibaar en vinnig veranderend gesien word en omdat slegs die proses ' $n$ meer blywende en legitieme waarde het vir die leerlinge en nie die waarde-inhoude nie. Waardes wat nie deur leerlinge self gekies is nie, word nie as outentieke waardes beskou nie.

Hierdie proses van waarde-uitklaring vind volgens Simon et al. (1995:9, $10)$ in sewe stappe plaas, naamlik: 
- die uitoefening van 'n vrye keuse

- die maak van 'n keuse uit verskillende alternatiewe

- die maak van 'n keuse nadat die gevolge deurdink is

- die op prys stel en koestering van die keuse

- die bevestiging daarvan

- die oorgaan tot aksie op grond van jou keuse en

- die herhaling van jou optrede.

Die doelstellings van die benadering is kortliks dat die leerlinge hul eie waardes sal uitklaar, kies, die gekose waardes sal koester en daarvolgens sal optree.

Die metodes wat gebruik word om die doelstellings te bereik, is groepbesprekings van morele dilemmas, analise van kompeterende aannames, rangskikking van waardes in volgorde van belangrikheid, vraelyste oor persoonlike voorkeure, die "stem-tegniek", en die verhelderende respons.

- Die morele dilemmas wat bespreek word, is egter ver verwyderd van die leefwêreld van die leerlinge en het byvoorbeeld te doen met ' $n$ vrou wat oor 'n rivier vol likkewane wou kom by die man vir wie sy lief was, maar die kaptein van die rivierboot sou slegs bereid wees om haar oor te neem indien sy sou inwillig om by hom te slaap ("The alligator river story" in Simon et al., 1995:230).

- Die karakters in die morele dilemmas is nie verbind aan enige spesifieke tradisie, plek of geskiedenis nie en die stories word onvoltooid beëindig. Kilpatrick (1985:82-83) wys op die feit dat daar by die morele dilemmas geen poging aangewend word om karakter uit te beeld nie.

- Geen onderskeid word getref tussen wat jy graag wil doen en wat behoort gedoen te word nie. Nêrens word gesuggereer dat sekere waardes beter of slegter as ander is nie en daar is geen regte of verkeerde keuse nie, slegs keuses wat jou gemaklik of ongemaklik laat voel

- Daar word geen onderskeid getref tussen morele en nie-morele waardes nie, want vrae soos die volgende word gevra, sonder om 'n poging aan te wend om die morele vrae van die nie-morele vrae te skei: Hoeveel van julle hou van joghurt? Hoeveel van julle hou van pieknieks? Hoeveel van julle dink aborsies moet gewettig wees? Hoeveel van julle keur huwelike tussen homoseksueles goed?. Die indruk word geskep dat waardes bloot 'n kwessie van persoonlike smaak is en dat moraliteit deur die meerderheidstem bepaal word. Die 
Waarde-uitklaring: Trojaanse perd in Suid-Afrikaanse skole?

invloed van groepsdinamika en portuurdruk word nie in aanmerking geneem nie.

- By die verhelderende respons moet die onderwyser ook deurgaans neutraal bly. "The idea without moralising, is to raise a few questions, leave them hanging in the air and move on" (Raths et al., 1966:51). Die verhelderende response plaas die verantwoordelikheid van waardekeuses uitsluitlik by die leerling

In die proses word die onderwyser slegs as die neutrale fasiliteerder beskou wat leerlinge help om duidelikheid te kry oor hulle waardes; hy/sy tree nie op as morele model of as verteenwoordiger van die samelewing se waardes nie. Die taak van die onderwyser is om leerlinge te help om veilig en gemaklik te voel oor hulle keuses en ook om hulle aan te moedig om die gaping tussen die waardes wat hulle kies en hul optrede te vernou. Die onderwyser moet deurgaans daarop bedag wees om enige vorm van moralisering, kritiek of evaluering te vermy, asook enige rigtinggewende vrae wat moontlik die meerderwaardigheid van een waarde bo ' $n$ ander suggereer. Die leerlinge se waardes moet gerespekteer word, of die onderwyser daarmee saamstem of nie en sy rol is bloot dié van 'n neutrale fasiliteerder.

\subsection{Beklemtoning van emosie}

Op die buiteblad van die gewilde handboek Values clarification (Simon, et al., 1995) staan: "The classic guide to discovering your truest feelings, beliefs, and goals", waardeur die belangrike rol van emosies by die uitklaring van waardes beklemtoon word. Die benadering gaan uit van die veronderstelling: "Our values are based on our feelings" (Simon, et al., 1995:10). Die feit word beklemtoon deur keusevrae soos: Waarvan hou jy die meeste? Waarvan hou jy die minste? Hoe voel jy oor...? Die klem val op dit wat vir my goed en lekker voel en nie op wat behoort gedoen te word nie. In bogenoemde aanhaling is daar 'n onbewuste erkenning dat sekere waardes meer eg of waar is as ander. Waarheid word gelykgestel aan gevoelens, terwyl gevoelens by uitstek wispelturig is.

\section{Kritiese evaluering van die benadering}

Nieteenstaande die feit dat die voorstanders van die benadering sterk gekant is teen enige vorm van indoktrinasie waaronder hulle enige tradisionele vorm van morele rigtinggewing en respek vir kernwaardes reken, indoktrineer hulle leerlinge tot etiese relatiwisme. Waar die individu sentraal gestel word en sy gevoelens en emosies die hoogste norm vorm by die keuse van waardes, is relativisme onvermydelik. Die 
belangrikste kritiek teen die model is dan ook dat dit aanleiding gee tot die ontwikkeling van relatiwiteit. Die programme van dié benadering is in werklikheid indoktrinasie in die waardes wat as belangrik beskou word naamlik selfverwesenliking, narsistiese selfbevrediging en die hoogtyviering van eie begeertes en regte.

As gevolg van ons multikulturele, diverse samelewing waar daar na dekades van afsondering nog die sterk teenwoordigheid van groepsbewussyn is, is daar in die jong demokrasie nog weinig sprake van gemeenskaplikheid, veral ten opsigte van gedeelde waardes. Omdat ons maar onlangs verander het na 'n demokratiese bestel, het SuidAfrikaners nog weinig ervaring van demokratiese waardes in die praktyk. Dit sou 'n wanopvatting wees om van die veronderstelling uit te gaan dat mense reeds oor 'n gemeenskaplike basis van kernwaardes beskik wat hul morele keuses ondersteun. Inteendeel, daar is vandag dikwels sprake van 'n morele vakuum en morele verwarring. Indien die vorm van morele relativisme wat die waarde-uitklaringsbenadering voorstaan, in skole die botoon sou voer in die afwesigheid van 'n stewige fondament van basiese kernwaardes wat reeds gevestig is, kan dit tot morele ongeletterdheid aanleiding gee

Daar is 'n ongelukkige parallel tussen die moreel outonome leerling wat volgens die waardeuitklaringsbenadering die enigste bepaler van waardes is en die wyse waarop jeugdige kriminele dink.

Criminals believe that whatever they want to do at any given time is right for them ... Despite his knowledge of what is legal and illegal, the criminal decides that he can make exceptions for himself, just because it suits him at a particular time. The fact that he wants to do it, makes it right (Samenow, 1984:62).

Omdat alle waardes gerelativeer word, word die kontroversie oor watter waardes in skole gevestig behoort te word, vrygespring. In dié verband sê Lockwood (1976:155-156): “... a value education program which, perhaps, unwittingly, is grounded in ethical relativism must accept the possibility that its students will embrace ethical relativism as their moral point of view - clearly an achievement of dubious merit".

Die subjektiwistiese en relatiwistiese aard van die benadering oorbeklemtoon die outonomie van die individu met gevolglike verwaarlosing van en vyandigheid teenoor tradisionele waardes. Die benadering is egter glad nie so waarde-neutraal as wat voorgegee word nie. Die voorstanders van dié benadering is of nie deursigtig nie óf nie bewus van die waardes wat geïmpliseer word deur hul doelstellings en metodes nie. Die waarde van individuele vryheid, selfbewustheid en outonomie word voorveronderstel, alhoewel die bestaan van enige algemeen geldige 
waardes ontken word. Die voorstanders van die waarde-uitklaringsbenadering is sterk gekant teen die indoktrinasie van tradisionele waardes, maar hulle is self nie vry van indoktrinasie in die waardes wat vir hulle belangrik is nie, naamlik dié van bevrediging van eie begeertes en selfverwesenliking. Hulle is sterk gekant teen tradisionele morele opvoeding omdat hulle dit beskou as indoktrinasie, maar in werklikheid gaan dit nie om teenkanting van indoktrinasie per se nie, maar wel om die indoktrinasie van tradisionele waardes.

Daar is 'n afwesigheid van die besef dat die mens altyd binne 'n sosiale konteks optree, want volgens die benadering onder bespreking word waardes slegs deur die individu bepaal en nie ouers, onderwysers of die samelewing lewer enige betekenisvolle bydrae nie. Die ironie wat uit die oog verloor word, is dat leerlinge dikwels nie werklik toenemend hul eie waardes uitklaar nie, maar meer en meer uitgelewer is aan die waardes wat die media - veral die TV - asook hulle portuurgroep voorstaan. Dit sal in die volgende dekade duidelik word of die nuwer tegnologie soos die internet, selfs nog 'n magtiger invloed op waarde-keuses het. Die waarde-uitklaringsbenadering is naief in die aanname dat waardeoordele in ' $n$ vakuum kan plaasvind. Morele besluite vind altyd plaas binne 'n sosiaal-historiese konteks.

Omdat gesag in die persoon self gesetel is, word geen outoriteit van buite die individu erken nie. Daar is geen gesagsbeliggaming buite die persoon waaraan daar verantwoording gedoen moet word nie. Die waarde-uitklaringsbenadering impliseer dat enige direkte gesagsleiding deur volwassenes die kind ontneem van die geleentheid om self te kies en homself te verwesenlik. Persoonlike vryheid word as die hoogste waarde verhef - 'n waarde waaraan alle waardes ondergeskik is. Indien volwassenes nie duidelike riglyne neerlê waardeur die toelaatbare en ontoelaatbare van mekaar onderskei word nie en die nog nie volwasse kind daarom te gou gedwing word tot volwasse, onafhanklike besluitneming, word gevoelens van onsekerheid beleef, as gevolg van die afwesigheid van opvoedingsgesag wat hom/haar beveilig. Vanuit 'n suiwer opvoedkundige oogpunt is dit duidelik dat hierdie benadering onversoenbaar is met 'n pedagogiese beskouing van 'n volwassene as gesagsdraer in 'n opvoedingsverhouding.

Die feit dat die individu die enigste rol speel in die bepaling van waardes, lei tot 'n ongebalanseerde en skeefgetrekte individualisme soos duidelik blyk uit die volgende opmerking van 'n student:

Moral values cannot be taught and people must learn to use what works for them. In other words, 'whatever gets you through the night, it's alright'. The essence of civilization is not moral codes but individualism 
Jeanette de Klerk

The only way to know when your values are getting sounder is when they please you more (Kilpatrick, 1993:22).

Hierdie individualisme waar die individu se behoeftes en gevoelens die middelpunt vorm van enige waardeoordele gee aanleiding tot narsisme en etiese egoïsme. In The culture of narcissism gee Lasch (1978:31-50) 'n insiggewende beskrywing van 'n narsistiese persoonlikheid en in The rise of selfishness in America skryf Collier (1991:246-264) oor die etiek van die self en die gevolge van selfsugtigheid. Die teenoorgestelde van individualisme is egter net so gevaarlik, want reg en verkeerd kan ook nie maar bloot afhanklik wees van die meerderheidstem nie. Die teenpool van egoilstiese individualisme, naamlik populisme (mob control) is ook moreel onaanvaarbaar, want daardeur word die individu ontneem van persoonlike morele verantwoordelikheid.

Die oorbeklemtoning van persoonlike emosies by die keuse van waardes is gevaarlik, nie alleen omdat leerlinge later nie meer daarin slaag om tussen waardes en emosies te onderskei nie, maar ook omdat dit subjektiwiteit en 'n selfgesentreerde "ek-eerste"-houding bevorder. Dit gee aanleiding tot ' $n$ morele benadering van "alles is reg solank dit vir my goed voel". In sy klassieke werk wat onmisbaar is vir enige gesprek oor moraliteit, het Alasdair Maclntyre (1984:21) gewaarsku dat die oorbeklemtoning van emosies bydra tot die agteruitgang van moraliteit.

' $n$ Verdere onderliggende probleem by en gevaar van die benadering is die feit dat waarde-neutraliteit soms in opvoedingsituasies immoreel kan wees. Die vraag kan gevra word of dit nie immoreel is vir 'n onderwyser om nie standpunt in te neem in 'n debat oor eerlikheid nie. Damon (1988:136) vra in die verband: "Are there not indeed some values that are so central to humanity in general, that positions of neutrality relative to them become morally unacceptable?" Dié dilemma word verwoord deur 'n onderwyseres wat die waarde-uitklaringsbenadering volg.

I don't expect them all to agree with me: each has to satisfy himself according to his own conviction, as long as he is sincere, and thinks he is pursuing what is right. I often discuss cheating this way, but I always get defeated because they will argue that cheating is alright (Sommers, 1984:383).

Sommige voorstanders van dié benadering het hierdie tekortkoming erken en gee toe dat:

.. emphasis on value neutrality probably did undermine traditional morality ... and that it would have been better had they presented a more balanced picture, had they emphasised the importance of helping students both to clarify their own values and to adopt society's moral values (Harmin, 1988:28) 
Waarde-uitklaring: Trojaanse perd in Suid-Afrikaanse skole?

Wat is dan die morele inhoud van die waarde-uitklaringsbenadering? Die benadering kan in der waarheid beskryf word as amper inhoudloos en Bennett en Delattre (1978:86) som dit soos volg op: "People are bundles of wants; the world is a battlefield of conflicting wants; and no one has room for goodness, decency or the capacity for a positive exercise of will". Daar word slegs gedink in terme van die regte begeertes en behoeftes van die individu en die onderliggende vraag na watter soort mens jy is, na jou karakter, word nie gevra nie.

'n Groot leemte in die benadering is die feit dat geen aandag geskenk word aan die vorming van morele gewoontes nie en die konsep van deugde en karakter is heeltemal afwesig

The problematic nature of the approach is that it denies the most important part of morality, which is not the development of decisionmaking capacities, the development of what used to be called, and can still be called, character - that is dispositions and habits of the mind and heart (Bennet \& Delattre, 1979:8)

Terwyl die integrering van waardes en die komplekse, veeldimensionele en tydsame vorming van karakter uit die oog verloor word, word moraliteit gereduseer tot ' $n$ blote eendimensionele saak van persoonlike keuses wat hoofsaaklik berus op gevoelens.

Die benadering onderskei nie tussen morele en nie-morele waardes nie en aangeleenthede soos of jy baie of min tyd buitenshuis bestee, kom in die oefeninge saam met ingewikkelde morele kwessies soos byvoorbeeld aborsie voor. Baie van die oefeninge hou geen verband met moraliteit nie, waardeur die verskille tussen morele aangeleenthede wat ook op ander ' $n$ impak het - en nie-morele aangeleenthede uitgewis word.

Waar sou die benadering inpas ten opsigte van die oorgang tussen die 20ste-eeuse modernistiese denke en die postmodernistiese denke? Dit reflekteer elemente van albei. Die waarde-uitklaringsbenadering vorm deel van die modernistiese tradisie in die sin dat dit die individu sentraal stel, die realisering van die potensiaal van die individu beklemtoon en glo in die moontlikheid van 'n neutrale keuse tydens waardevorming. Maar daar is ook eienskappe wat deel is van die postmoderne tradisie, waarvoor daar geen vaste verwysingspunte is nie, omdat dit nie gaan om 'n spesifieke stel waardes nie. Die inhoudloosheid van die benadering gee aanleiding tot morele verwarring. Sonder 'n objektiewe morele verwysingspunt buite hulle self kan kinders nie 'n gevoel van reg en verkeerd ontwikkel nie. In die artikel "Are moral values enough?" wys Habgood (1990:109-110) op die neiging om morele waardes te grond in menseregte, omdat die taal van menseregte ' $n$ internasionale taal is en 
nie gekoppel word aan 'n bepaalde geloof of godsdiens nie. Die hele menseregtebenadering berus egter histories op ' $n$ implisiete moraliteit wat afkomstig is vanuit religieuse oortuigings.

Thus when we ask what it is which undergirds such assertions as the equality of all people or the dignity of the individual, it is difficult to avoid tracing the connections back to traditional Protestant ideas about personal relationship with God (Habgood, 1990:109, 110).

In 'n kritiese bespreking van die waarde-uitklaringsbenadering is dit onvermydelik om by die vraag stil te staan of die benadering enigsins versoenbaar is met die Christelike siening oor moraliteit soos gegrond op die Skrif. Die uitgangspunte van die humanistiese beweging waarop die waarde-uitklaringsbenadering gebaseer is, is om verskeie redes onversoenbaar met die Christelike geloof. Die Christelike beginsels van nederigheid, selfopoffering, selfbeheersing en kuisheid is in sterk kontras met die humanistiese ideologie van regte, wat maksimum individuele vryheid verkondig in die soeke na selfaktualisering (Visser \& Potgieter, 1994:494). Waar individuele waardes vir die humanis die deurslaggewende rol speel, is dit vir die Christen meer kompleks, want individuele waardes moet oorweeg word in die lig van geloofswaardes. Vir die Christen is die mens en sy emosies en begeertes nie die finale maatstaf of kriteria van goed en kwaad nie, en reg en verkeerd is nie maar 'n kwessie van persoonlike smaak nie. Die egosentriese individualisme van die humanisme word deurbreek en ondergeskik gestel aan die interpretasie van die goddelike wil in die lewe van die Christen. Christenskap impliseer ' $n$ ander stel waardes, ' $n$ ander verstaan van die belangrikheid van dinge as dié van die nie-Christen en 'n nederige afhanklikheid van God.

Die humanis se geloof in die mens as van nature goed, is direk in kontras met die Bybelse siening oor die gevalle mens wat na die sondeval geneig is tot alle kwaad en daarom ook moet leef uit die besef van persoonlike vergiffenis en verlossing. Indien die mens van nature goed is en net moet leer om homself te aanvaar en homself te aktualiseer, kan dit logies geargumenteer word dat die kruisdood van Jesus Christus onnodig is, omdat dit nie in ooreenstemming met die natuurlike goedheid van die mens is nie. Die oorbeklemtoning van die self, wat neig tot seltverheerliking en die klem op selfverwesenliking, is in direkte teenstelling met die Christen se opdrag om homself te verloën. In die Humanistiese Handves $11 \mathrm{nr} .1$ (1973) word die doel van die mens as selfaktualisering beskryf. Daar word beweer dat die Christelike geloof met die klem op afhanklikheid meer as onafhanklikheid, gehoorsaamheid eerder as selfbevestiging, hierdie doel verydel. Die humanis verwerp ook die Christelike beskouing van die sondige natuur van die mens en sien 
Waarde-uitklaring: Trojaanse perd in Suid-Afrikaanse skole?

sonde as ' $n$ vorm van valse skuldbewussyn wat ' $n$ belemmering is op die mens se pad na selfaktualisering.

Die opdrag in Spreuke 22:6 "Gee leiding aan 'n jong mens oor hoe hy moet leef, en hy sal ook as hy al oud is nie daarvan afwyk nie", staan in direkte kontras met die neutrale fasiliteerder van die waarde-uitklaringsbenadering wat nooit voorskriftelik mag optree nie. Opvoeding is 'n lewensopvatlike aangeleentheid en daarom is dit nooit neutraal nie. Binne die Christelike denkraamwerk is opvoeding altyd normgerig en opvoeding gaan om die wek van 'n sin vir waardes. So 'n uitgangspunt staan in direkte kontras met die waardeneutrale benadering van waardeuitklaring. Die duidelike opdrag aan gelowige ouers in Deuteronomium 6:4-9 sal deur die voorstanders van die waarde-uitklaringsbenadering as outoritêre indoktrinasie beskou word.

Die afwesigheid van gesag is ook vanuit 'n Christelike oogpunt onaanvaarbaar. Dit is telkens in die Skrif (vgl. Fil 6:1-4, Spreuke 22:15 en 29: 17) duidelik dat daar van opvoeders verwag word om kinders te dissiplineer. Dobson (1980:206) sê in dié verband:

.. we have departed from the standard which was clearly outlined in both the Old and New Testaments, and that deviation is costing us a heavy toll in the form of social turmoil. Self-control, human kindness respect, and peacefulness can again be manifest if we dare to discipline in our homes and schools.

Gelowige ouers sien hul kinders as God se kinders en daarom is hulle voor God verantwoordelik vir die wyse waarop hulle hul kinders opvoed. Ouers wat by die doop van hul kinders belowe om hul kinders volgens Christelike norme en waardes op te voed en te laat opvoed, kan nie maar sonder meer die waarde-uitklaringsbenadering in skole aanvaar nie. Onder Christelike norme en waardes word breedweg verstaan 'n waardestelsel wat die Bybel as die gesaghebbende Woord van God aanvaar en wat spruit uit geloof in God (Van Wyk, 1996:533). Die waarde-uitklaringsbenadering wat morele relatiwisme as basis het en selfgerigtheid en selfsugtigheid deur die oefeninge aanmoedig, is nie in ooreenstemming met die Christelike lewensbeskouing nie en daarom onaanvaarbaar vir die ouer wat die reg het om toe te sien dat die waardes wat op skool versterk word, in ooreenstemming is met die waardes van sy Christelike lewensfilosofie.

Vir die Christen is opvoeding deur God daargestel om sy Raadsplan te voltrek en indien dit ontken word, word opvoeding uitgelewer aan sekularisme en humanisme (Van der Walt, 1992:92-93). Dit is dan een van die grootste gevare van die waarde-uitklaringsbenadering, want waar daar geen erkenning van Goddelike gesag is nie en die mens en sy 
gevoelens en begeertes die enigste morele maatstaf vorm, is die mens uitgelewer aan selfgesentreerde eiebelang. "Neutraliteit teenoor die geestelike vorming van die kind lei tot verheerliking van die selfgenoegsame mens" (Van Staden, 1995:468). Dit is dan ook onvermydelik die gevolge van die benadering.

\section{Toepaslikheid in die Suid-Afrikaanse konteks}

Dit lyk oënskynlik asof die waarde-uitklaringsbenadering toepaslik is vir Suid-Afrikaanse skole, omdat dit 'n oplossing bied vir die probleem van pluraliteit en multikulturalisme. Die groot klem op die individu se wense en begeertes is dan ook in ooreenstemming met die sterk beklemtoning van die regte van die individu in ons nuwe grondwet. Dié benadering is dan ook in ooreenstemming met die postmoderne tendense van relatiwiteit, onsekerheid en die afwys van Groot Narratiewe. Die positiewe van die benadering is dat dit aanleiding kan gee tot 'n verskerpte bewussyn vir konflikterende waardes asook vir die belangrikheid van verdraagsaamheid en 'n nie-veroordelende houding teenoor individue met ander waardes.

Die Suid-Afrikaanse gemeenskap is 'n hoogs heterogene gemeenskap. "The cultural diversity which is characteristic of most modern communities results in individualism" (Badenhorst, 1992:2). Gemeenskaplike waardes is egter die sement waarsonder geen samelewing kan funksioneer nie. "No nation in history has survived for long without a basic consensus on values ..." (Gairdner, 1993:20). Eers wanneer daar reeds ' $n$ toereikende gemeenskaplike basis van kernwaardes gevestig is - waardes waaroor die meeste Suid-Afrikaners saamstem, gevestig is en deugde reeds ' $n$ integrale deel van die morele mondering van leerlinge uitmaak, kan die waarde-uitklaringsbenadering as 'n opsie oorweeg word om verdere helderheid te verkry oor reeds gevestigde waardes. Die risiko van die waarde-uitklaringsbenadering kan dus net bekostig word waar daar reeds 'n breë konsensus oor basiese waardes bestaan. Dit is daarom duidelik dat 'n groot mate van bestaande morele konsensus 'n voorvereiste is vir die geslaagde toepassing van 'n benadering wat implisiet staatmaak op die inherente en ontwikkelde morele verantwoordelikheid van individue. Die bestaan van konsensus oor gemeenskaplike waardes in die morele en kulturele pluralisme van ons samelewing word egter toenemend bevraagteken.

Die verwarring en onsekerheid wat die waarde-uitklaringsbenadering skep, kan aanleiding gee tot groter verdeeldheid en konflik, want wat gebeur indien individue se uitgeklaarde waardes in botsing kom met mekaar? 
Waarde-uitklaring: Trojaanse perd in Suid-Afrikaanse skole?

Because value clarifiers emphasize individual and personal concerns, the problem of value conflict within the theory has not been well addressed. Yet the paradox of the theory is that it not only helps clarify certain values well but also causes increased confusion when it is obvious that 'clarified values' can conflict, within oneself and between persons (Hersh et al., 1980:94-95).

\section{Gevolgtrekking}

In 'n land wat meer en meer in die rigting van die disintegrasie van morele waardes beweeg, waar ouers as primêre opvoeders dikwels nie meer hul plig as morele opvoeders nakom nie en positiewe morele rolmodelle in die media en die samelewing al hoe minder word, word die taak van die onderwyser as morele opvoeder nog meer deurslaggewend. Onderwysers is nodig, nie as blote neutrale fassiliteerders nie, maar as mense wat deur hul voorbeeld, optrede as morele modelle en deur hul onderrig, waardes soos integriteit, eerlikheid, hardwerkendheid en regverdigheid by leerlinge kan vestig.

Indien die waarde-uitklaringsbenadering kritiekloos aanvaar word in Suid-Afrika deur ouers en onderwysers wat daarin 'n uitkoms sien vir die komplekse waardedebat, kan dit net soos die Trojaanse perd, tot selfvernietiging aanleiding gee. Christen-ouers en -onderwysers behoort bedag te wees op die voor- en nadele van die benadering en behoort dit te evalueer in die lig van hulle Goddelike opdrag. Die waarde-uitklaringsbenadering wat oënskynlik na 'n oplossing mag lyk vir die probleem om waardes in Suid-Afrikaanse skole te vestig, kan in werklikheid 'n morele bedreiging inhou. Die regte van ouers en beheerliggame om die etos van 'n onderwysinrigting te bepaal is daarom van kardinale belang en ouers sal nie meer bloot as passiewe toeskouers kan optree ten opsigte van die vestiging en uitbou van waardes in skole nie.

In die vorige bedeling was staatskole in Suid-Afrika met allerei wetgewing, reëls en regulasies beskerm teen oortuigings en waardestelsels wat nie fundamenteel Christelik was nie. Dit was volgens Van Wyk (1996:534) nie alleen beperkend nie, maar het ook dikwels tot morele korrupsie in ons midde aanleiding gegee. Die situasie is egter vandag heeltemal anders en die klimaat in skole is nou sodanig dat die waardeuitklaringsbenadering in talle skole verwelkom sal word as 'n oplossing vir die dilemma om waardes te vestig. Die Trojaanse perd moet egter ook nie summier verwerp word nie, want die proses van waardeuitklaring kan 'n geleentheid aan Christene bied om self hul Christelike norme en waardes uit te klaar, dit te bevestig en daarom die waardes met oortuiging uit te leef. 
Jeanette de Klerk

\section{Bibliografie}

BADENHORST, D.C. 1992. The limitations and possibilities of the South African Education System in the inculculation of values. Scriptura, Mei (41):1-12

BENNET, W.J. \& DELATTRE, E.J. 1978. Moral education in the schools. The Public Interest, 50:81-98

BENNET, W.J. \& DELATTRE, E.J. 1979 A moral education: Some thought on how to best achieve it. American Educator, 3(1):6-8.

COLLIER, J.L. 1991. The rise of selfishness in America. New York : Oxford University Press.

DAMON, W.D 1988. The moral child: Nurturing children's natural moral growth London : Macmillan

DOBSON, J.D. 1980. Dare to discipline. Eastboume : Kingsway

GAIRDNER, W.D. 1993. The war against the family. Toronto : Stoddart

HABGOOD, J. 1990. Are moral values enough? British Journal of Educational Studies, 38:106-115.

HARMIN, M. 1988. Value clarity, high morality: Let's go for both. Educational Leadership, 45(8): 24-30.

HERSH, R H., MILLER, J.P \& FIELDING, G.D. 1980. Models of moral education: An appraisal. New York : Longman.

Humanist Manifesto 11 (1) 1973. New York: Prometeus Books

KILPATRICK, W.K 1985. The emperor's new clothes. Illinois: Good News Publishers

KILPATRICK, W.K. 1993. Why Johnny can't tell right from wrong. New York: Simon \& Schuster

LASCH, C. 1978. The culture of narcissism. New York: Norton

LICONA, T. 1991. Educating for character. How our schools can teach respect and responsibility. New York: Bantam Books.

LOCKWOOD, A 1976. A critical view of values clarification. (In Purpel, D. \& Ryan, K., eds Moral education: It comes with the territory. Berkeley: McCutchan p. 155-165.)

MacINTYRE, A 1984. After virtue: A study in moral theory. Notre Dame : University of Notre Dame Press

RATHS, L. HARMIN, M \& SIMON, S. 1966. Values and teaching. Ohio: Merrill

SAMENOW, S.E. 1984. Inside the criminal mind. New York: Random House.

SIMON, B.S., HOWE, L.W. \& KIRSCHENBAUM, H. 1995. Values clarification: A practical, action-directed workbook. New York: Warner Books.

SOMMERS, C.H. 1984. Ethics without virtue: Moral education in America American Scholar. 381-389, Summer

VAN DER VEN, J.A 1998. Formation of the moral self. Cambridge : Eerdmans.

VAN DER WALT, J.L. 1992. Fundamentele opvoedkunde en die ontisiteit van opvoeding. Pretoria : RGN Uitgewers

VAN STADEN, J.G. 1995. Die godsdiensneutraliteitsbeginsel van die Amerikaanse demokrasie. Koers, 60(30):459-473

VAN WYK, W.C. 1996. Christelike norme em waardes in onderwys en opleiding Hervormde Teologiese Studies, 52(283):532-545

VISSER P J \& POTGIETER JM 1994. Some critical comments on South Africa's bill of fundamental human rights. Tydskrif vir Hedendaagse Romeins-Hollandse Reg, 57(3):493-498 
Waarde-uitklaring: Trojaanse perd in Suid-Afrikaanse skole?

Kernbegrippe:

morele opvoeding

waarde-uitklaringsmodel

Key concepts:

moral education

value clarification 